\title{
Analysis on E-Commerce Crisis in China in the International Trade Environment
}

\author{
Yanmei Li \\ School of Economics, Jinan University, Guangzhou, China \\ Email: 523092760@qq.com
}

Received 7 January 2016; accepted 22 January 2015; published 25 January 2016

Copyright (C) 2016 by author and Scientific Research Publishing Inc.

This work is licensed under the Creative Commons Attribution International License (CC BY). http://creativecommons.org/licenses/by/4.0/

(c) (i) Open Access

\begin{abstract}
The update and development of e-commerce have brought new opportunities and challenges to enterprises in China. E-commerce promotes the formation of global market. It reduces the trade cost, improves the trade efficiency, improves customer satisfaction, etc. According to the characteristics and advantages of electronic commerce, this article uses the literature data method, the data statistics method to our country electronic commerce in the international trade to carry on the detailed analysis. This study provides the theoretical basis for the avoidance of crisis and stable development of electronic commerce in international trade. Conclusion: It is proposed that when e-commerce is applied in international trade in China, infrastructure shall be updated; the research and development of security technology shall be paid attention to; laws and regulations shall be improved; and the seamless integration with international trade is required.
\end{abstract}

\section{Keywords}

China, Electronic Commerce, Trade Crisis

\section{The Characteristics of E-Commerce and Its Impact on International Trade}

\subsection{The Characteristics of E-Commerce}

\subsubsection{Business Technicalization}

The modern information technology promotes the development of e-commerce. E-commerce can be only operated with modern information technology. Through the computer and relevant communication tools, the modern information technology service system is built. The most common work includes program design, remote service, website establishment, some computer maintenance, etc. The development of e-commerce starts from the editing of information on the mobile terminal. Through the establishment of website, information is posted on the website, and transactions are conducted in the network environment. From the imperfect beginning to gra- 
dual improvement, everything is closely related to modern information technology.

\subsubsection{Business Globalization}

E-commerce has the global market not limited by space and time. The global e-market is realized with multimedia technology and mobile Internet. This is an independent "global" market. No matter where the consumers or the sellers are, they can enjoy the convenient service brought by e-commerce and enter the digital consumer market by connecting to the Internet with their mobile devices.

\subsubsection{Trade Intellectualization}

The continuous renewal of modern information technology and the development of e-commerce are very fast. The scope of the people's daily trade will extend to technology and knowledge they own. In the process of international trade, capital is distributed by people with skills and knowledge. With the improvement of technical content of trade goods, products will become intelligent in future.

\subsubsection{High Efficiency of Trade}

Compared to traditional business activities, modern business has lower transactional capital, effective inventory management, shorter production cycle, more business opportunities, less excessive use of physical equipments, etc. E-commerce saves transactional capital in the trade, transportation cost and purchasing cost [1]. Second, e-commerce integrates work in the process of business activities into a set with the Internet. Through processing and classification of the information in the set, the flow speed of cost of capital is increased, and the efficiency of management is effectively improved, so as to create new profits. With the development of e-commerce, compared with the traditional trade, e-commerce saves costs and creates profits. In the near future it will replace the traditional mode of trade.

\subsection{The Impact of E-Commerce on International Trade}

\subsubsection{E-Commerce Leads the International Trade}

The development of the society promotes the development of the trade, and will inevitably produce the new mode of trade. E-commerce has more advantages than the traditional mode of trade. In order to prevent the price war in trade, e-commerce must create more business opportunities, and improve the transaction efficiency by lowering the transaction cost and creating trade opportunities, such as multimedia teaching of the Internet, medical consulting of the Internet, Internet shopping, etc. E-commerce is a new means of exchange, but like the traditional means of exchange it should be combined with the physical mode [2]. In our daily life, for example, by searching market data, product advertising and sales model in each region, using e-commerce we can complete the transaction. E-commerce is not bound by time or space. It allows information resources to be shared globally, and promotes fast and good development of international trade.

\subsubsection{E-Commerce Promotes the Globalization of International Trade Environment}

The trading environment of e-commerce is established on the virtual Internet. Through the Internet the trade information is materialized. It creates a new physical trade market, breaks through the traditional regional market, and establishes a global market through the network. The synchronized information communication can be realized in Europe, America, Asia and Africa. The information flow in the global market promotes capital flow and technology sharing. Finally with the update of the virtual Internet technology and operation simplification, the global network trade in the electronic environment gives more cooperation opportunities to different continents.

\subsubsection{E-Commerce Reforms the Mode of Operation of International Trade}

Network technology makes the enterprise publicity and marketing simple. The Internet can quickly display products and related services. For example, Lenovo's official website provides online computers, mobile phone, maintenance, consulting and other services in China, Hong Kong, the United States, etc. International trade uses the interactive network operation mechanism of e-commerce to establish the complete market environment, breaks through the logistic-centered pattern across national borders, and establishes the new logistics system with the form of cash flow, the core of information flow and the main body of commodity flow [3]. Producers, consumers and traders replenish stock through the interactive network operation mechanism, and shorten the 
time of commodity logistics through the intangible means of exchange, but in the national trade information entrustment and agency relations in different regions have difference, so it may cause the reform of the international trade business management [4].

\subsubsection{A New Trade Form Is Produced}

International information trade is the first industrial revolution in the history of mankind. With information industry, the new trade is opened up. In the society of knowledge explosion, knowledge is the first element of production. Through the advanced information technology, knowledge can be transferred. The information industry is the basic industry in the industrial structure in the future, and the source of power driving the development of global economy. E-commerce improves the efficiency of the international trade, and increases the varieties of trade commodities. Information trade has become a new and independent form of trade. The international trade will derive a series of commodity trade, service trade and so on [5].

\section{Analysis on the Crisis of E-Commerce in China in the International Trade}

At the beginning of the reform and opening up, with the development of electronic technology and Internet technology, the Chinese government had poor performance in promoting the application of e-commerce to international trade activities, but it played an important role on the development of e-commerce in China [6]. In the present stage e-commerce technology in China is difficult to face the problem of the development of international e-commerce. In international trade e-commerce in China will have a series of crisis.

\subsection{Transaction Delay Crisis}

The development of e-commerce cannot go without the Internet. Development of the Internet is slow in China. The number of Internet users increases fast. The current e-commerce needs cannot be met. Based on the characteristic of the large population in China, compared with that in developed countries per capita education level is low. The limited number of people knowing the computer technology greatly limits the development of e-commerce in China [7]. As a result, China must invest heavily in the construction of basic Internet network, and accelerate the construction of national information. The backward informatization will restrain the development of economic globalization. China's information technology has made some achievements, but it is still in the preliminary stage. Due to the unfavorable factors such as unreasonable network planning, slow network and high network cost, China fails to combine with more advanced e-commerce. Small and medium-sized enterprises play an important role in the social development in China. They lack the supporting service network technology. The utilization rate of e-commerce of small and medium-sized enterprises in the international trade activities is less than $10 \%$. They only contribute to $0.12 \%$ of GDP in China. The level of the Internet in China is low, there is a lack of investment, there is no core technology, and equipments have to be imported, which severely limits the full coverage of information network in China and delays the trading.

\subsection{Transaction Security Crisis}

Through the Internet e-commerce trade changes the physical commodity information, goods flow and capital into digital to transfer trading. In the process of trading, e-commerce safeguards the interests of consumers and merchants. The digital banks are realized, and mobile devices replace the manual operation of bank window, such as "online banking" on the Internet, mobile phone software mobile banking, alipay and We Chat Wallet. The digital payment method needs physical banks. Banks are the centre of the trade. Digital payment is a new payment method produced in the information age. Digital payment is the online payment. Through the network customers, merchants and banks use electronic virtual money, bank account and other means to transfer funds the corresponding units. Trading produces capital. In the process of international trade, capital circulation is the key, and virtual electronic money is the basis for trade. It involves all aspects of suppliers. E-commerce law is not sound. In the process of national trade, the e-commerce transactions will also face crisis from all sides. For example, if the electronic account is stolen, the disclosure of business secrets will cause the hazard of instability. In case of dispute on money, it will be a very terrible problem, so the core issue of e-commerce trade is the payment security. The Internet also has its own limitations. The network transactions are still under various threats. Such transactions bring challenges. This threat is mainly embodied in the hacker attack of server. By 
cutting, translating and changing the network information, hacker cheats consumers or merchants. Research data shows that $35 \%$ of e-commerce users think that the biggest problem of online trading is security [8]. The problem of security of online payment has not been solved yet. Security will limit the application of e-commerce in business trade.

\subsection{Tax Mechanism Crisis}

\subsubsection{The Standing Body Has Limited Jurisdiction}

The principle of standing body has an important significance in the field of international tax. For example, after the standing body is established in China and the territorial tax jurisdiction is obtained, tax can be collected from the standing body. In the global e-commerce environment, residents of different countries or regions can trade on a global scale. How can we identify the standing body of non-local users? For example, if merchants use VPN for long-distance login of website for product sales and other services, the standing body can't be collect tax. Domestic consumers often buy commodities in foreign countries through the e-commerce. If the commodity is sold in the United States, we can't collect taxes on American commodity. Therefore, the existing policies are unable to solve the problems such as warranty service and subsidy policy.

\subsubsection{The Nature of the Income Tax Is Difficult to Determine}

In tax laws and regulations, there are different forms of tax for the income gained by the use of tangible and intangible property. Commodities in e-commerce transactions can be divided into tangible and intangible commodities. The payment method can be divided into direct trading of tangible commodities and direct trading of intangible commodities. The examples of direct trading of tangible commodities include purchasing of mobile phones, computers, bike and others on Jingdong Mall. As for the direct trading of intangible commodities, for example, payment for renewal of warranty of computer on Lenovo's official website is intangible commodity. E-commerce transfers the tangible commodities into data and displays to the clients, such as online payment for buying iTunes books, mp3 and others on the apple website. However, there is still no unified standard for determining whether it is income from provision of services or selling of commodities.

\subsubsection{The Tax Jurisdiction Is Not Clear}

Different tax jurisdictions are not the same. Usually the jurisdiction in the place of income is preferred. E-commerce makes transactions electronic. Consumers do not have to go out. Therefore, due to uncertain trading place, tax jurisdiction is able to play its due role. Tax evasion and tax avoidance becomes easier. The concealment and uncertainty of the e-commerce transactions has uncontrollable influence on taxation. We can't clearly obtain the tax basis, so tax evasion and tax avoidance becomes easy for taxpayers.

\subsection{Crisis of Loopholes in Laws and Regulations}

Compared with the physical business, e-commerce lacks complete laws and regulations for restriction and standardizing of the trade. Because e-commerce is quantitative and qualitative, it is hard to for make laws. Government departments shall lead. The information industry, financial industry and other industries shall participate in the discussion. The high informatization of e-commerce has created a new mode of trade. The old trade law cannot adapt to the new mode of trade. The application of China's current e-commerce to international trade is not mature. Especially in the process of trade there is no specific legal document for electronic payment security problem, electronic contract dispute problem, etc. There are three problems at present. First, inconsistent legal contract rules are inconsistent. The terms in the print contract include specific time, place and people, as well as fingerprints, while some terms and rules of e-commerce contract are unclear, which brings instability to the convenience of both parties. Second, the identity of legal person is unclear. At present the true identity of legal person in e-commerce transactions still cannot be confirmed. In the process of trading, it gives consumers unreal consumption, and it is likely to disclose consumers' information. Third, the legal rules have defect. For example, traditional contracts are handwritten and signed, while e-commerce contract only has the online digital signature or password composed of a series of numbers. The traditional cash transaction changes into a habit of electronic online signature. It is also a kind of digital electronic transaction status. The payment method has changed, but relevant laws have not been updated in a timely manner. There is no specific provision of the legality of electronic data in the law. 


\section{E-Commerce Crisis Prevention Advices}

After China joined WTO, China's export trade has a certain status in the world, and the e-commerce trade gradually replaced the old mode of trade. Only by developing and updating e-commerce, China can stand out in the international electronic trade and promote the development of the domestic economy. Therefore, the weaknesses of e-commerce in China can be remedied from the following four aspects.

\subsection{Update the Infrastructure}

The development of e-commerce must be based on the electronic facilities. Compared with the e-commerce trade in the United States and Germany, the electronic trade in China is relatively backward, mainly because at present the foundation of electronic information equipments is weak in China. Let's look at the construction of network equipments in China. The network is developed in few coastal areas such as Guangdong, Shanghai and Beijing. The network settings in other provinces are relatively backward. Due to backward electronic equipments, China's e-commerce economy develops slowly, and is far behind that in the developed countries. Therefore, in order to promote the essential progress of e-commerce in China, now the most important task is the fast and high-quality all-round construction of the electronic network infrastructure, in order to keep up with the pace of international trade.

\subsection{Pay Attention to the Research and Development of Security Technology}

The development of e-commerce trade in China faces the technical challenges. The trade is related to banking institution, tax institution, insurance institution, etc. To promote the development of e-commerce in China, different institutions must work together. Currently for the research on the e-commerce transaction security technology, electronic authentication, cash payment and other technologies, different institutions must strengthen communication, cooperation and study, catch up with the development speed of the Internet, and strive to improve the electronic information technology in China in a short period.

\subsection{Improve Laws and Regulations}

International trade law has a history of more than 20 years. This law is only for the mode of trade on paper. Most regulations of international trade law are not applicable to the e-commerce. At the same time, it brings inconvenience to e-commerce keeping pace with the times. In order to ensure the orderly development of e-commerce in China, for the information security, intellectual property right, payment security and other problems, we must combine with the actual situation and develop the electronic trade regulations conforming to the present situation.

\subsection{Connect with the International Trade}

The e-commerce beyond the boundaries of time and space promotes the economic globalization. E-commerce also has imperfect parts, such as customs tax, digital intellectual property rights, means of payment and other problems. The positive global economic integration can reduce unnecessary disputes. On the international trade seminars and dialogue, our government must strengthen the contact with the outside world and strive to integrate into the big market of international trade.

\section{References}

[1] Liu, F. and Zou, C.H. (2009) Introduction to the Close Relationship between E-Commerce and Logistics Industry. China, 10, 71-72.

[2] Ni, Y. (2006) Study on the International Trade Practice under the Condition of Informatization in China. Information Science, 24, 1481-1485.

[3] Yue, W.L. and Zhu, K.L. (2014) Research on Development Strategies of the Logistic Industry in the E-Commerce Environment. Chinese and Foreign Entrepreneurs, 34, 41-43.

[4] Chen, Y.Z. (2002) Exploration and Analysis on the Principle Problems of Standing Body in E-Commerce Environment. International Economic Law Review, 5, 493-495.

[5] Fu, X. (2010) Present Situation of and Thinking about China’s E-Commerce Legislation. China Science and Technol- 
ogy Information, 20, 193.

[6] Liu, X.H. (2007) Discussion about the Impact of E-Commerce on the Development of International Trade in China. Market Modernization, 1, 105-106.

[7] Mou, X.G. (2006) The Application of E-Commerce in International Trade and the Problems. Science and Technology Plaza, 10, 51-52.

[8] Wu, Y.L. (2012) Study on the Problem of E-Commerce Safety Payment. Electronic Technology, 3, 14-16. 